\title{
A new genus of tragulid ruminant from the early Miocene of Kenya
}

Israel M. Sánchez, Victoria Quiralte, Jorge Morales, and Martin Pickford

Acta Palaeontologica Polonica 55 (2), 2010: 177-187 doi: http://dx.doi.org/10.4202/app.2009.0087

We re-describe the type material of the tiny African tragulid "Dorcatherium" moruorotensis from the early Miocene of Kenya, and erect the new genus Afrotragulus, the first African Miocene tragulid that does not belong to Dorcatherium. This new taxon is characterized by its elongated and stretched lower molars with a unique morphological dental pattern that strongly contrasts with that of Dorcatherium. We additionally include the former "Dorcatherium" parvum, also a small species from the early Miocene of Kenya, into the new genus Afrotragulus as Afrotragulus parvus, figuring it for the first time. We discuss the usefulness of body size as the main taxonomical criterion for studying the Tragulidae. And finally we comment on the taxonomical and morphological diversity of tragulids in the moment of their sudden early Miocene re-apparition and expansion in the Old World.

Key words: Afrotragulus, Dorcatherium, Tragulidae, Ruminantia, early Miocene, Moruorot Hill, Rusinga Island, Kenya, Africa.

Israel M. Sánchez [israelms@mncn.csic.es], Department of Zoology, Museum of Zoology, University of Cambridge, Downing Street, Cambridge, CB2 3EJ, United Kingdom; Departamento de Paleobiología, Museo Nacional de Ciencias Naturales- CSIC. C/ José Gutiérrez Abascal 2, 28006 Madrid-Spain;

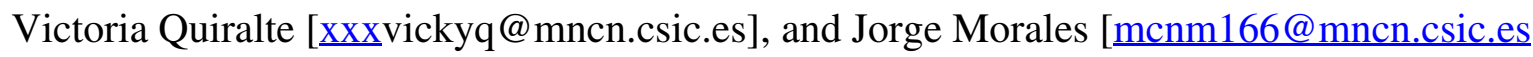
], Departamento de Paleobiología, Museo Nacional de Ciencias Naturales-CSIC,. C/ José Gutiérrez Abascal 2, 28006 Madrid-Spain; Martin Pickford [pickford@ mnhn.fr], Département "Histoire de la Terre", UMR 5143 du CNRS, case postale 38, 8, rue Buffon, 75005 Paris, France.

This is an open-access article distributed under the terms of the Creative Commons Attribution License (for details please see creativecommons.org), which permits unrestricted use, distribution, and reproduction in any medium, provided the original author and source are credited. 
Fof Full text $(602.4 \mathrm{kB})$ 